\title{
The paradox of the serrated sickle erythrocyte: The importance of the red blood cell membrane topography.
}

\author{
Samir K. Ballas \\ Thomas Jefferson University \\ Philippe Connes \\ University Claude Bernard Lyon
}

Follow this and additional works at: https://jdc.jefferson.edu/cardeza_foundation

Part of the Hematology Commons

Let us know how access to this document benefits you

\section{Recommended Citation}

Ballas, Samir K. and Connes, Philippe, "The paradox of the serrated sickle erythrocyte: The importance of the red blood cell membrane topography." (2015). Cardeza Foundation for Hematologic Research. Paper 40.

https://jdc.jefferson.edu/cardeza_foundation/40

This Article is brought to you for free and open access by the Jefferson Digital Commons. The Jefferson Digital Commons is a service of Thomas Jefferson University's Center for Teaching and Learning (CTL). The Commons is a showcase for Jefferson books and journals, peer-reviewed scholarly publications, unique historical collections from the University archives, and teaching tools. The Jefferson Digital Commons allows researchers and interested readers anywhere in the world to learn about and keep up to date with Jefferson scholarship. This article has been accepted for inclusion in Cardeza Foundation for Hematologic Research by an authorized administrator of the Jefferson Digital Commons. For more information, please contact: JeffersonDigitalCommons@jefferson.edu. 


\section{The paradox of the serrated sickle erythrocyte: The importance of the red blood cell membrane topography}

Samir K. Ballas MD ${ }^{1}$ and Philippe Connes $\mathrm{PhD}^{2}$

${ }^{1}$ Cardeza Foundation for hematologic Research, Department of Medicine, Jefferson Medical

College, Thomas Jefferson University, Philadelphia, PA

${ }^{2}$ Laboratory CRIS-EA 647 - Section "Vascular Biology and Red Blood Cell”, University Claude Bernard Lyon 1, Villeurbanne, France

Correspondence:

Samir K. Ballas MD FACP

Cardeza Foundation

1020 Locust Street

Philadelphia, PA 19107

E-mail: Samir.ballas@jefferson.edu

Phone: 856-745-6380

Fax: 856-795-0809

Short title: The serrated sickle erythrocyte

Key words: sickle, topography, serrated sickle

Abstract word count: 79

Total word Count: 583 excluding references and legends 


\begin{abstract}
Red blood cell rheology and adhesiveness play a key role in the occurrence of vaso-occlusive like events in sickle cell anemia. The present paper reviews counter-intuitive findings supporting that rigid and serrated sickle red blood cells do not initiate vaso-occlusion. Instead, the less rigid red blood cells could initiate vaso-occlusion because of their increased adhesiveness to the vascular wall. We suspect that stiffness of sickle erythrocytes and the topography of RBC membrane are factors affecting adhesion to the endothelium.
\end{abstract}


Literally, "sickle" refers to an agricultural instrument with a short handle and a crescent-shaped wooden structure that is used for reaping or cutting down tall grass and weeds. In stone-age times a variant of the sickle had serrated blades made of naturally occurring volcanic glass (obsidian) or flint to increase its efficiency in cutting (Fig. 1 and 2). Ironically, some sickle erythrocytes do have serrated surface that could be one sided or circumferential (Fig. 3). Other investigators referred to such cells as "Holly Leaf" sickle cells [1, 2]. The shape of sickled cells depends on the rate of deoxygenation. The serrated shape is the result of intermediate rate of deoxygenation causing the formation of smaller domains of short aligned fibers [3]. Slow deoxygenation generates the classic sickle cell morphology due to the formation of single domain of well-aligned fibers [3]. Serrated sickled cells are rigid with decreased deformability and are found in the ISC dense fraction of red blood cells separated on Stractan II [4].

The peripheral smear shown in Fig. 3 is from a 31 year-old African American man with sickle cell anemia. Past medical history was significant for infrequent vaso-occlusive crises (VOC) at a rate of $\leq 1$ per year. Other complications included history of leg ulcers and cholelithiasis. His $\mathrm{Hb}$ was $6.4 \mathrm{~g} / \mathrm{dL}$, Hct 18.5\%, MCV 90 fl, MCHC $34 \mathrm{~g} / \mathrm{dL}$, reticulocyte count $16 \%$ and Hb F $2 \%$. The number of irreversibly dense cells (ISC) was $27 \%$ which included both crescent-shaped and serrated erythrocytes.

Previous studies have indicated a paradoxical effect of the rheological properties of RBC on the clinical picture of SS. Traditionally, it has been thought that a low percentage of ISC, a low percentage of dense cells, and a high degree of deformability are beneficial factors and should ameliorate the severity of SS. It turns out that these factors have the opposite effect. Patients (both adults and children) who have decreased cell deformability and increased number of ISC and dense cells have mild disease with respect to the VOC [5-7]. A subsequent study showed patients whose RBC deformability averaged $37 \%$ or less of control values and whose dense cells averaged $22 \%$ of total circulating cells had fewer VOCs, less mortality, higher incidence of leg ulcers, and lower incidence of urinary tract infection although their $\mathrm{Hb} \mathrm{F}$ was relatively low [8]. These findings are supported by another recent study [9]. In addition, it has been reported that sickle cell anemia with the highest reduction of RBC deformability were at lower risk to have osteonecrosis [10], another complication for the vaso-occlusive phenotype [11]. This suggests that the stiff ISC does not deform to establish contact with endothelial cells to initiate adhesion and consequent vascular occlusion. The serrated cell, likewise, does not initiate adhesion because the corrugated membrane topography prevents or minimizes the establishment of contact between the ligand and its receptor between the endothelium and the serrated RBC. Thus stiffness of sickle erythrocytes and the topography of RBC membrane seem to be factors that affect adhesion to the endothelium. 


\section{Legends to Figures}

Figure 1. A stone age serrated sickle tool. Adapted from an image at the European Virtual Musuem (http://www.europeanvirtualmuseum.it/).

Figure 2. Sickle tool from the Neolithic Age. Photo from Wolfgang Sauber. Museum Quintana Neolithische Sichel. (http://en.wikipedia.org/wiki/Sickle\#mediaviewer/File:Museum_Quintana__Neolithische_Sichel.jpg)

Figure 3. Peripheral smear from a patient with sickle cell anemia showing numerous ISCs and serrated sickle cells (Arrows). 


\section{References}

1. Lei, H., and Karniadakis, G.E., "Predicting the morphology of sickle red blood cells using coarse-grained models of intracellular aligned hemoglobin polymers." Soft Matter vol. 8, pp., 2012.

2. Natarajan K, Townes TM, and, and Kutlar A. (2010) Disorders of Hemoglobin Structure: Sickle Cell Anemia and Related Abnormalities. In: Williams Hematology. Kaushansky K, and et al eds. New York, NY: McGraw Hill, pp. 709-742.

3. $\quad$ Eaton, W.A., and Hofrichter, J., "Hemoglobin S gelation and sickle cell disease." Blood vol. 70, pp. 1245-1266, 1987.

4. Clark, M.R., Mohandas, N., Embury, S.H., and Lubin, B.H., "A simple laboratory alternative to irreversibly sickled cell (ISC) counts." Blood vol. 60, pp. 659-662, 1982.

5. Ballas, S.K., Larner, J., Smith, E.D., Surrey, S., Schwartz, E., and Rappaport, E.F., "Rheologic predictors of the severity of the painful sickle cell crisis." Blood vol. 72, pp. 12161223, 1988.

6. Lande, W.M., Andrews, D.L., Clark, M.R., Braham, N.V., Black, D.M., Embury, S.H., and Mentzer, W.C., "The incidence of painful crisis in homozygous sickle cell disease: correlation with red cell deformability." Blood vol. 72, pp. 2056-2059, 1988.

7. Lamarre, Y., Romana, M., Waltz, X., Lalanne-Mistrih, M.L., Tressieres, B., DivialleDoumdo, L., Hardy-Dessources, M.D., Vent-Schmidt, J., Petras, M., Broquere, C., Maillard, F., Tarer, V., Etienne-Julan, M., and Connes, P., "Hemorheological risk factors of acute chest syndrome and painful vaso-occlusive crisis in children with sickle cell disease." Haematologica vol. 97, pp. 1641-1647, 2012.

8. Ballas, S.K., "Sickle cell anemia with few painful crises is characterized by decreased red cell deformability and increased number of dense cells." Am J Hematol vol. 36, pp. 122-130, 1991.

9. Bartolucci, P., Brugnara, C., Teixeira-Pinto, A., Pissard, S., Moradkhani, K., Jouault, H., and Galacteros, F., "Erythrocyte density in sickle cell syndromes is associated with specific clinical manifestations and hemolysis." Blood vol. 120, pp. 3136-3141, 2012.

10. Lemonne, N., Lamarre, Y., Romana, M., Mukisi-Mukaza, M., Hardy-Dessources, M.D., Tarer, V., Mougenel, D., Waltz, X., Tressieres, B., Lalanne-Mistrih, M.L., Etienne-Julan, M., and Connes, P., "Does increased red blood cell deformability raise the risk for osteonecrosis in sickle cell anemia?" Blood vol. 121, pp. 3054-3056, 2013.

11. Kato, G.J., Gladwin, M.T., and Steinberg, M.H., "Deconstructing sickle cell disease: reappraisal of the role of hemolysis in the development of clinical subphenotypes." Blood Rev vol. 21, pp. 37-47, 2007. 


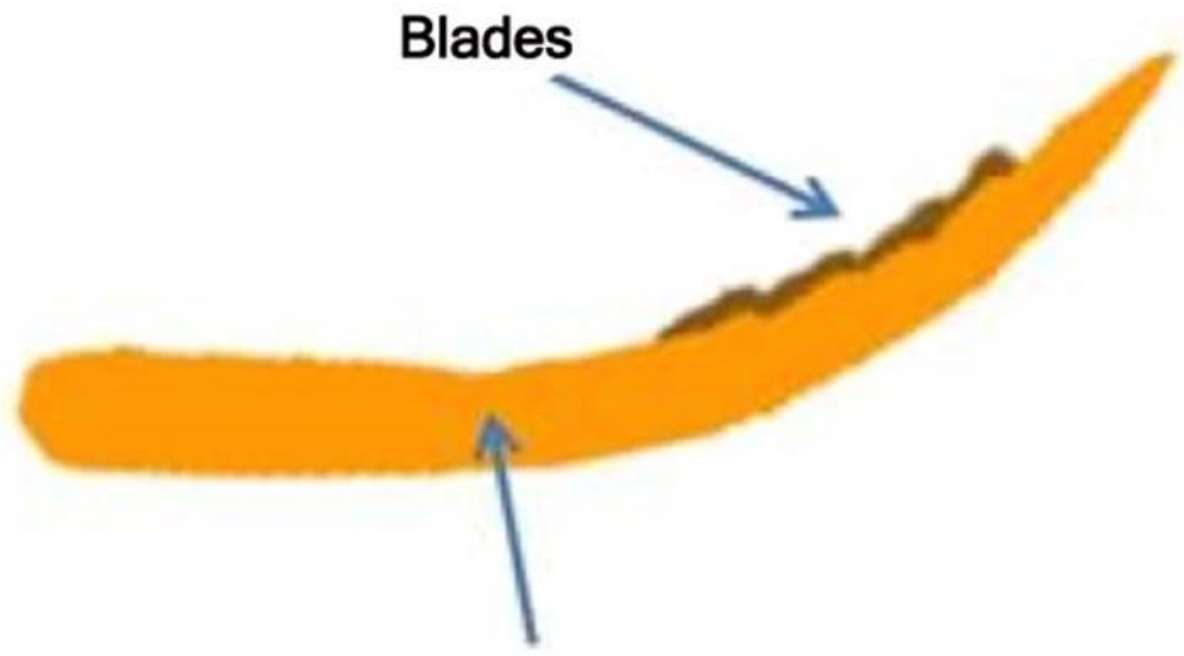

Wooden or bone structure

Figure 1 


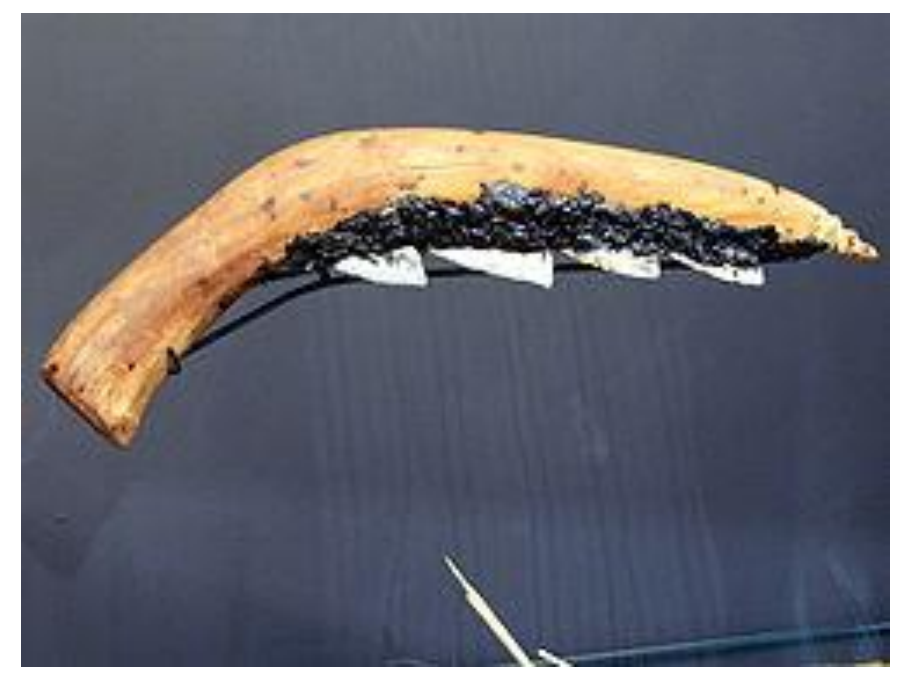

Figure 2 


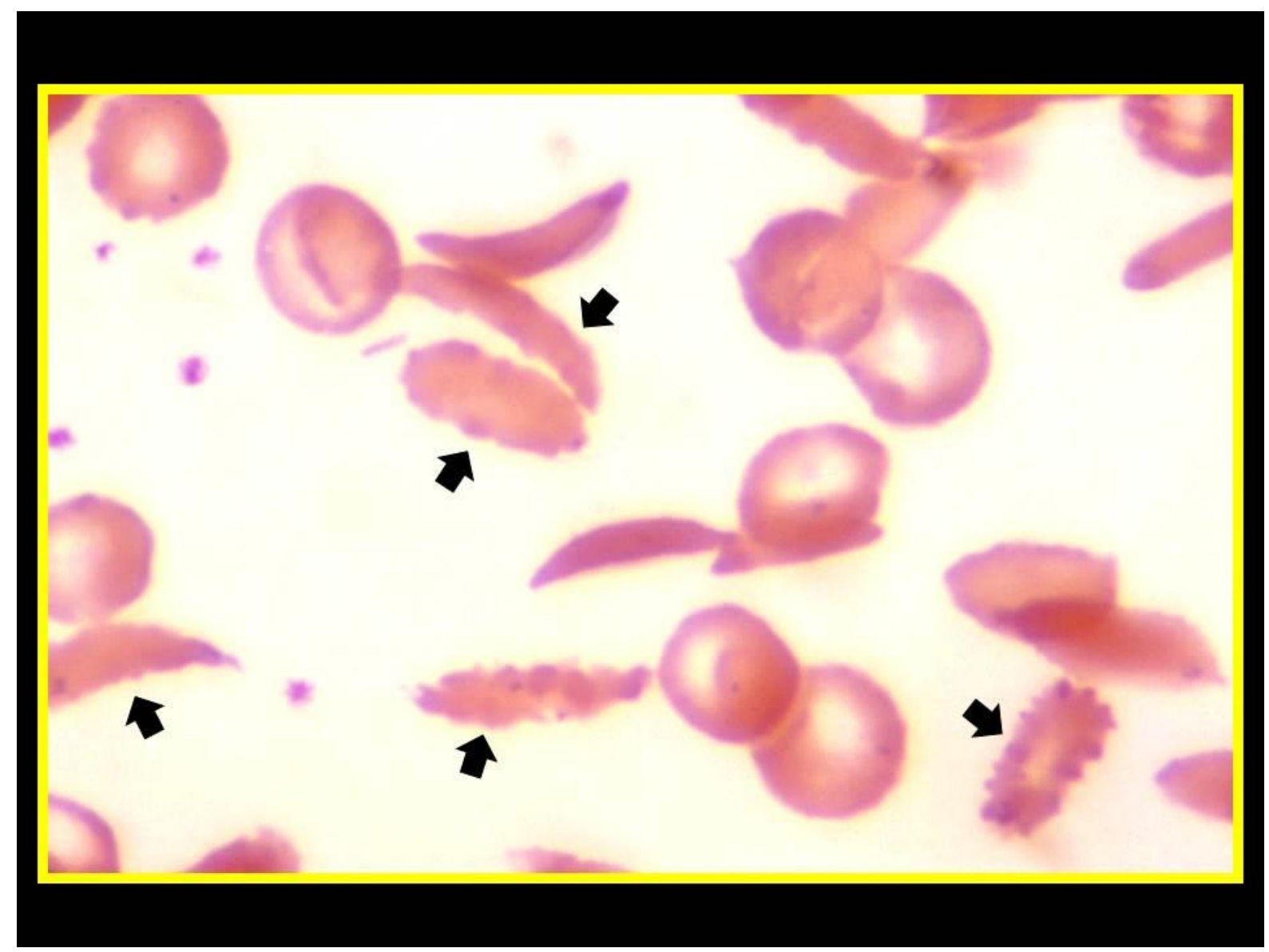

Figure 3 